Article

\title{
"I Have Come Not to Abolish but to Fulfil": Reflections on Understanding Christianity as Fulfilment without Presupposing Supersessionism
}

\author{
Jesper Svartvik
}

Citation: Svartvik, Jesper. 2022. “I Have Come Not to Abolish but to Fulfil": Reflections on Understanding Christianity as Fulfilment without Presupposing Supersessionism. Religions 13: 149. https://doi.org/ 10.3390/rel13020149

Academic Editor: Randall

C. Zachman

Received: 19 November 2021

Accepted: 2 February 2022

Published: 7 February 2022

Publisher's Note: MDPI stays neutral with regard to jurisdictional claims in published maps and institutional affiliations.

Copyright: (c) 2022 by the author. Licensee MDPI, Basel, Switzerland. This article is an open access article distributed under the terms and conditions of the Creative Commons Attribution (CC BY) license (https:/ / creativecommons.org/licenses/by/ $4.0 /)$.
Center for Christian-Jewish Learning, Boston College, Chestnut Hill, MA 02467, USA; jesper.svartvik@bc.edu
Abstract: This article explores the interrelationship between the two major issues that the theologians of earliest Christianity were pondering, i.e., how to explain the suspension of the eschaton, and how to understand the relation between Christ believers and the people of Israel. Whereas within a couple of decades a number of answers were already given to the former question in order to appease the questioners and marginalize the topic, the answer to the latter question has been not only formative for all Christian thinking for two millennia, but also utterly destructive for Jewish-Christian relations throughout the ages. This article recognizes that after two thousand years of supersessionism, it takes a lot of work to articulate a Christian theology which is fulfilment without supersessionism-but not as much work as the first generations of Christ believers had to devote to de-eschatologizing their message in order to be able to hand it over to future generations of Christians. They prevailed the challenge of their time-will we?

Keywords: supersessionism; fulfilment; Christianity; Judaism; Paul; Krister Stendahl

\section{Introduction}

In his book The Political Theology of Paul, Jacob Taubes recounts a story about his friend Krister Stendahl.

"I want to tell you a story ... I have a very good friend-now he's a bishop in Stockholm, he used to be a professor at Harvard, where I knew him well-Krister Stendahl. And I remember (I'm telling you this as a personal story), he visited me once in New York, and we were standing in front of a very large fireplace. And Krister-he's a real warrior type, you know, Goebbels would have envied him his figure-he says to me that his deepest worry is - he belongs (we were speaking English) to the "commonwealth of Israel". So I said to myself, Krister, you superAryan from Sweden, at the end of the world, as viewed from the Mediterranean, other worries you don't have? No, he has no other worries! There I saw what Paul had done: that someone in the jungles of Sweden-as seen from where I'm standing-is worrying about whether he belongs to the "commonwealth of Israel," that's something that's impossible without Paul. (I was able to reassure him: as far as I'm concerned he's in.)" (Taubes 2004, p. 41)

It seems fitting to begin this article with this quotation because this story has very much to do with the topic we are about to explore, i.e., the interplay of Christian selfunderstandings and Jewish-Christian relations.

This article takes as its starting point the two major issues that the theologians of earliest Christianity were pondering, i.e., how to explain the suspension of the eschaton, and how to understand the relation between Christ believers and the people of Israel. Whereas within a couple of decades a number of answers were already given to the former question in order to appease the questioners and marginalize the topic, the answer to the latter question has been not only formative for all Christian thinking for two millennia, but 
also utterly destructive for Jewish-Christian relations throughout the ages. This answer to the question of how the Jewish people are related to Christ believers is known as supersessionism, i.e., that the Christian Church has replaced the Jewish people. Given, firstly, that supersessionism has played such a fundamental role in Christian theology in all its various traditions-Oriental, Orthodox, Catholic, and Reformed-, and, secondly, that Christians now seek an alternative to expressing its relation to the Jewish tradition, to what extent and in what way can Christianity be understood as "fulfilment"?

\section{Two Challenges for Earliest Christianity}

The theologians of the early Christian movement were struggling primarily with two issues, the first of which is addressed in the very oldest Christian text that has been handed down to posterity, i.e., First Thessalonians, written approximately in the year 50 C.E., see, e.g., 4.16f.:

16 "For the Lord himself, with a cry of command, with the archangel's call and with the sound of God's trumpet, will descend from heaven, and the dead in Christ will rise first. ${ }^{17}$ Then we who are alive, who are left [Greek: epeita hêmeis hoi zôntes hoi perileipomenoi], will be caught up in the clouds together with them to meet the Lord in the air; and so we will be with the Lord forever."

We see here that questions about the suspension of the eschaton-i.e., how Christians could cope with the fact that Christ believers passed away before the return of the Christhad to be answered. The answer that Paul gives reveals that he was confident that he himself would be one of "those still alive" (hoi zôntes hoi perileipomenoi) when all this would take place. In the earliest Christian text that has survived, the author clearly believes that the eschaton was, at most, a few years away.

The second question in the early Christian movement was the relation between Christ believers-i.e., gentile Christ believers - and the people of Israel. What were the gentile Christ believers? Who were they? Why were they what they were? Within a few decades, Christians would define themselves as "Israel," the "true Israel," and, eventually, the "new Israel," and when doing so, they defined themselves at the expense of the Jewish people, who had forfeited its covenantal framework-and therefore, Israel was portrayed as a people with bane only, and no blessings. Randall Zachman has argued that this supersessionism is the most ecumenical Christian notion:

"When taken together, the understanding of the Jews as a uniquely punished and exiled people may truly be the most universal of all Christian doctrines, for as we shall see, until fairly recently it has apparently been believed and taught everywhere, always, and by all". (Zachman 2019, p. 51)

In other words, all Christians have always agreed that there is something fundamentally flawed with post-biblical Judaism. We encounter one early mirror image of Christian supersessionism in the rabbinic text Tanchuma, where Moses is asking to have not only the written Torah in writing but also the oral Torah. However, the Holy, Blessed One turns down his request, and the argument is that the Mishnah has to remain a secret, i.e., oral, because in times to come the nations of the world will rise and claim: "We are Israel". (Tanchuma, ed. Shlomo Buber, Wayera 6. Cf. Pesiqta Rabbati, ed. Ish Shalom, 5). In order to prove who really are Israel, the oral tradition must remain the common secret of Israel and God.

We all know that supersessionism early on became the Christian way to understand its relation to the Hebrew Scriptures and the Jewish people, i.e., that the essence of the life, death, and resurrection of the protagonist of the New Testament was that carnal Israel be replaced by the Church.

However, a growing number of New Testament scholars are convinced that this was not how the very earliest Christianity defined itself. At that time, the question was whether there were good theological arguments in favor of a "gentile inclusion". Even to consider that the message of the historical Jesus of Nazareth was to convince fellow Jews not to be 
loyal to their covenant with God, and to proclaim a theology of "Jewish exclusion," is, if not impossible, at least implausible.

How are we to understand this gentile inclusion? Paul's own expression is that nonJews are grafted into the olive tree of the covenant (see Rom. 11.11-24); Paula Fredriksen has suggested that non-Jewish Christ believers were "eschatological pagans," prepared for the eschaton (e.g., Fredriksen 2015, p. 645). Earliest Christianity saw itself-in one way or another-as intrinsically related to another people: hoi Ioudaioi, what used to be translated quite simplistically as "the Jews," but nowadays much more often as "the Judeans," one reason being that it emphasizes the link between peoplehood and religion. When we use the translation "the Judeans," we more clearly see that the implications of Christian supersession are not only theological in the strictest sense of that word, but also national, ethnic with consequences for our understanding of peoplehood. Paula Fredriksen claims that Paul argued for a gentile inclusion in terms of land, blood, language, and religion, i.e., in terms of peoplehood (Fredriksen 2017, pp. 148-51).

In this context-i.e., the intersection of supersessionism and peoplehood-one is reminded of an excellent article by Yvonne Sherwood, because it highlights the similarities between supersessionism and colonialism. The title of the article says it all: "'Colonizing the Old Testament' or 'Representing Christian Interests abroad': Jewish-Christian Relations across Old Testament Territory". She elegantly and painfully shows how Christians have argued that Jews have mismanaged their territory, and that it, therefore, is, so to speak, "white men's burden" to take it over and rename it "Old Testament" (instead of the terminology of, so to speak, the "native" language, which is "Tanakh") (Cf. Sherwood 2000).

One could picture this as Christian colonialism going all the way back to a bright afternoon when two distinguished Christian gentlemen sat in the shadow on a porch somewhere in the Mediterranean area and, enjoying a gentle breeze from the sea, with the Hebrew Scriptures in front of them on the table, they gave the tome the name "Old Testament," which is so much easier to pronounce than the "aboriginal" and therefore incomprehensible expression "Tanakh."

This article emphasizes the consequences of supersessionism because it was formative for Christian thinking. David Nirenberg has stated that anti-Judaism, a critical thought in the Western tradition, has often imagined itself as an overcoming of Judaism, and therefore, it has the capacity to introduce Judaism in whatever it criticizes (Nirenberg 2013a, 2013b).

\section{Three Bad Choices}

This article argues that there are three fundamental and bad choices in Christian history. Slavery is not one of them, because Christianity never chose slavery; it was born into a world of slavery, where one third or two thirds of the population in any given city were slaves, and it has certainly thrived in slave societies, with the U.S. antebellum South being the most notorious example. Eventually, Christians chose to refute slavery; it took eighteen hundred years, but finally they did (e.g., Glancy 2002).

Nor is it patriarchy, because Christianity never chose patriarchy; it was there, all around, two millennia ago in the Roman Empire, what Elisabeth Schüssler Fiorenza calls "kyriarchy" (e.g., Schüssler Fiorenza 1993). Christianity is still seeking to overcome it and to present Christian faith in a way that manifests "the radical notion that women are people" (Shaer 1986, p. 6; Sayers 2005).

However, three times in history Christianity chose fundamentally wrong. Starting with the most recent and going back in time: the third bad choice was the headlock with science in the wake of the Enlightenment; numerous Christians argued and believed that one has to choose between evolution and religious beliefs, between Charles Darwin's The Origin of the Species and the first chapters in the book of Genesis. The second bad choice was that it went to bed with power, and Jesus' vision of a Kingdom of God was transmuted into the Empire of Christendom. Finally, the first and fundamental choice was that Christianity stole the book of the Jewish people and regarded it as its own. Partly, this was a reaction to an inner-Christian debate: whereas Marcion stated that the Bible was so Jewish that it 
was not Christian at all, the more influential theologians of Christendom replied that the Hebrew Scriptures (to be read in translation) were so Christian that they were not Jewish at all. As the famous saying goes, Christians chose a Jewish God, but spurned the Jews (e.g., Ucko 1994, p. 1). Peoplehood was taken, not achieved; whereas Paul wanted to convey a message of gentile inclusion, Christendom preferred to proclaim Jewish exclusion. Hence, supersessionism is no marginal issue, it is the first major mistake Christendom made-to be followed by more-and we still suffer from the consequences. It was a formative moment in the history of Christianity, when this identity was stolen, at the expense of others. This theft could be described as the original sin of Christian theology: its consequences constantly resurface, up until today, in all areas of theology.

Going back to the two first major theological questions in early Christianity, if one had a bent for being a pessimist, one could say that they were mistaken with regard to the first question (on the delay of the eschaton), and with reference to the second question, they eventually got that one wrong, too. This should give us pause.

However, an optimist would point out that during the post-Second World War period, Christians have spent a lot of energy and time on finding ways to correct the second mistake: supersessionism has been rejected by a number of the major Christian denominations. Needless to say, a lot of work remains to be done, but the first critical and crucial steps have been taken. As regards the first questions-the suspension of the eschaton-already within the New Testament, we see how Christians learnt to deal with that issue. Could one not say that this is the first time they sought to articulate Christian theology without explicit references to what the Nazarene had taught them? Theology does not consist of simply reciting authoritative teaching, but also of learning from history and applying the teaching in new-i.e., never foreseen-contexts. This may be one of the most palpable examples of the fact that the church is not only ecclesia docens ("the teaching church"), but also ecclesia discens ("the learning church").

In other words, we are here analyzing two errors, although of very different kinds: whereas the first one was due to a lack of knowledge-and two decades later, they gained this knowledge, or perhaps "insight" is a better word in this context-the second was the result of theological triumphalism, which is far more difficult to detect and resist. It took two millennia for Christians to start contesting this legacy, and it seems that this battle is constantly about to begin: in every Christian congregation, in every classroom at a theological seminary, and in every Christian theological document on the relation between the Old Testament and the New Testament, and between Judaism and Christianity.

\section{Three Foundational New Testament Texts}

Inter-religious relations and dialogue can and should inform, form, and transform intra-religious discourse. ${ }^{1}$ The Jewish-Christian dialogue helps us to see that there is not only one starting point for Jewish-Christian relations in the New Testament, as if this were the "biblical" foundation. There are, without doubt, several possible points of departure. One is here reminded of the fact that the Greek word biblia means "books," i.e., "many books"; hence, a "library". Hence, I wish to explore the consequences of entering through three different doors into this biblical library. Paul's Epistle to the Romans is undoubtedly one of the most important Christian documents. Martin Luther wrote in his preface to that letter that Christians should know the text by heart and study it daily. Romans remains one of the most significant texts for Christians seeking to express their faith. For this reason, three foundational passages in Romans have been chosen which may serve as three doors into the biblical library.

When entering the first door, we find the first text, which is the tenth chapter in Romans, especially its fourth verse: "For Christ is the end of the law so that there may be righteousness for everyone who believes". Rom. 10.4 has governed the agenda for Jewish-Christian relations to a remarkable degree-not least in Lutheran circles-in three respects:

1. Jewish-Christian relations have been defined by different understandings of the Law. 
2. The two religions have been classified as each other's opposites: whereas Judaism has been described as a religion of Selbsterlösung ("self-redemption"), Christians have understood themselves as liberated from this burdensome way of life. When Emil Schürer in his Geschichte des jüdischen Volkes im Zeitalter Jesu Christi wanted to describe Jewish life, he chose the astonishing expression Das Leben unter dem Gesetz ("Life under the Law"). (See the editors' comments in Schürer 1979, p. II.464.)

3. Judaism is depicted as a prologue to Christianity; Jesus of Nazareth is portrayed as the One who came to terminate Judaism. In other words, this is a model which emphasizes that Judaism belongs to the past; therefore, its adherents often find it difficult to perceive Judaism as a contemporary movement. It is not a matter of a distinct emphasis on only Rom. 10.4, but, rather, of a more or less accurate description of the role of the Law in Jewish thought; a more or less accurate description of the lack of such an emphasis in Christian theology, and also a perspective which consigns the momentum of Jewish-Christian relations to history: the riddle has already been solved, there are no loose ends, etc. It is essential to take notice of the prominent role which history plays in this first model: contemporary interreligious relations are governed by the past.

Needless to say, this model is marred by errors: firstly, Jewish "covenantal nomism," a term coined by E. P. Sanders, is more often than not misrepresented, and, secondly, according to this antithetical theology, Christianity falls prey to what Leo Baeck called "romantic religion," with mystery at the expense of commandments (Sanders 1977, p. 422; Baeck 1958, pp. 189-292, esp. p. 196). In addition to these two serious allegations, the exegetical foundation of this approach is somewhat flimsy. Biblical scholars continue to discuss plausible, possible, implausible, and impossible interpretations of telos nomou in Rom. 10.4. It is quite obvious that it need not necessarily mean "the end of the Law," since there are other instances in the New Testament where we interpret the word telos differently, e.g., 1 Tim. 1.5: " ... the aim [telos] of such instruction is love that comes from a pure heart, a good conscience, and sincere faith". Hence, we could easily understand Rom. 10.4 as a description of Christ being the "aim," "realization", or "fulfilment" of the Law.

When discussing Pauline theology and the Law, New Testament scholars agree in two respects and disagree in a third: (i) according to Paul, Christ was the fulfilment of the Law, because in and with him the promises given to the Mothers and Fathers were fulfilled. (ii) Paul was convinced that Christ was the end of the Law in the sense that Gentiles no longer needed to become proselytes in order to become members of the covenant. In the words of John Gager, "Paul's point is that a proper understanding of Scripture-of course, this means understanding Scripture in Paul's terms-shows that God had intended from the very beginning to redeem the Gentiles through Jesus Christ" (Gager 2002, p. 73). This is the reason for Paul's election of Abraham as the key figure in his theological treatises. Abraham was the first Gentile to become recognized as righteous without the Law (see, e.g., Rom. 4 and Gal. 3). (iii) Scholars disagree on the implications for Jews of Paul's emphasis on Gentile mission. I belong to those who find it implausible that he advocated that Jews no more should continue to live according to the covenantal commandments. Now, it is imperative to remember that when Paul lived, it was the two first-mentioned points which were truly revolutionary; in our day, we often seem to forget this, as our discussions move on to the third, difficult, perhaps never to be resolved question.

A growing number of scholars agree with Krister Stendahl that it is not a guilt-ridden Paul who uses the expression telos nomou in Rom. 10.4. He points out that "Guilt language, and the very word 'guilt,' do not occur in Paul" (Stendahl 1995, p. 29). Therefore, it is plausible that nomos here has less to do with our conscience and all the more to do with Jewish covenantal signs (e.g., food laws, Shabbat, and circumcision) as markers of identity. The introspective sin-centered reading will, however, continue to dominate, and not only in hard-core Lutheran circles. The best solution may simply be to find another opening for contemporary Jewish-Christian relations. Of course, we want biblical scholars to continue the debate on what Paul actually meant when writing Rom. 10.4, but we 
have to recognize that we cannot build Jewish-Christian relations on the interpretation of telos nomou. It is simply too shaky a foundation for thriving interfaith relations. It has already been mentioned that another problem with a theology which uses Rom. 10.4 as its foundation is its tendency to focus too much on the past tense: Judaism is far too often presented as the prologue of Christianity. Jesus of Nazareth is far too often presented as the One who ends Spätjudentum, to use the concept that that was coined in order to describe the fate of Judaism at the time of Jesus, which, according to this understanding, was about to cease to exist.

In other words, we need another way into Paul's Epistle to the Romans. We cannot continue to be dependent on what scholars say telos nomou in Rom. 10.4 once meant and how we apply it today. It does not seem to be a good starting point of improved Jewish-Christian relations. So, whither do we go?

The second door in this virtual tour of the biblical library takes us to the eleventh chapter in Romans and to Paul's famous discussion on different kinds of branches on the olive tree: some are natural; other are grafted onto the tree (11.16-24). Then follows a decisive statement (11.25f.): "I want you to understand this mystery [to mustêrion touto]: a hardening has come upon part of Israel, until the full number of the Gentiles has come in. And so all Israel will be saved [kai houtôs pas Israêl sothêsetai] ... "

Whereas the statement in Rom. 10.4, about Christ and the Law, often has served as a starting point for Lutheran musings on Jewish-Christian relations, Rom. 11 could be described as the foundation upon which Roman-Catholic theological reflection in the fourth paragraph of Nostra Aetate was built. The sharp-eyed reader of the Pauline epistles will detect an evolution in his soteriological reflection. The young Paul was convinced that he lived in the latter days and that all Gentiles would become Christians. He could not understand why not all fellow Jews would share his opinion. However, and this is important, the older Paul began to realize that he was actually wrong. Now, it was not the Gentile mission which he questioned; as far as we know, he defended it for the rest of his life. Nor was it the short perspective; he remained convinced that the end was near. The "intensity of Paul's eschatological commitment" did not diminish (Gager 2002, p. 74). The difference in perspective between Paul's older letters and those of a later date is that, when read in the light of each other, they indicate that we find, already in the Pauline epistles, the insight that the Jewish people in toto would not join the Christian movement. This is what motivates him to reflect on God's covenantal faithfulness. To put it differently, the young Paul opened a door for the Gentiles to enter the covenant. The older Paul opened another door in Christian thinking when reflecting on God's pre-Christian covenantal assignments with the help of the statement that "all Israel will be saved". Needless to say, soteriology is discussed in the rabbinic literature as well. It seems that the oldest account of the conviction that "all Israel has a share in the world to come" (kol Yisrael yesh la-hem cheleq la-'olam ha-ba) is found in Mishnah Sanhedrin 10.1, and, thus, can be dated to c. 200 C.E. Now, thanks to Rom. 11.25f., this tradition can be predated some one hundred and fifty years. (New Testament scholars who seek to establish the ipsissima verba Jesu apply the criterion of embarrassment. Is there something of an analogy here? Arguably, Paul refers to a tradition which, seemingly at least, causes difficulties for Christocentric soteriology.)

The eleventh chapter in Romans is more promising as a starting point for JewishChristian relations today than is the tenth. It is, nevertheless, problematic with such an entry. There are several problems involved here; for one thing, biblical scholars disagree on what Paul actually meant when he referred to the branches of the olive tree: who are the branches which are broken off? Who are the wild olive shoots which are being grafted on? Who is the root? Paul himself says that he is referring to "this mystery" (to mustêrion touto).

A second aspect is the text's distinctly eschatological emphasis. Whereas the first model (which was connected to Rom. 10.4) tended to reduce Judaism to a phenomenon in history, this second approach tends to authorize Jewish-Christian relations with reference to the future. It is not Jews living today who are in focus, nor is it contemporary Judaism which is being discussed. To put it bluntly, Jews are tolerated because of a Messianic 
theology which proclaims that in days to come, Jews will become Christians. Such an eschatological emphasis can be found in some circles of Evangelicalism.

It is symptomatic that so many Christians who meet Jews or who want to reflect on Jewish-Christian relations sooner than later tend to focus on soteriology. Why is it troublesome? (i) First, it is difficult for conservative Christians, since their soteriology is so Christ-centered that they are seldom capable of coping theologically with Jewish spirituality post Christum, and at times even with a graceful God in the Hebrew Bible, since, at times, these texts are reduced to a prolegomenon to the New Testament. (ii) Secondly, it is difficult for liberal Christians, because soteriology is not expressed in this way in their discourse. They prefer to refer to, for example, Jesus' statement in Lk. 19.9. When a tax collector-who most probably had become wealthy by robbing his fellow citizens-exclaims "Look, half of my possessions, Lord, I will give to the poor; and if I have defrauded anyone of anything, I will pay back four times as much," Jesus comments: "Today salvation [sôthêria] has come to this house, because he too is a son of Abraham". Liberal theologians remind other Christians that this is also a manifestation of salvation, but liberals, on the whole, are less inclined to use an individualistic soteriological discourse. (iii) Thirdly, it is difficult because the whole discourse is irrelevant to Jews. One is reminded of Benjamin Disraeli's famous statement that "nineteen centuries of Christian love have taken a toll". Jews have heard too much—not too little—about Christian soteriology.

Chapters 9-11 in Romans have always been central for Christians interested in JewishChristian relations. Some Christians have emphasized Rom. 10.4, while others prefer to refer to the parable of the olive tree in Rom. 11. In the first case, Judaism is easily reduced to a prologue in history and Christianity to its termination. In the latter model, true Judaism, at times, seems to be relegated to the future. Christians relate to Jews and Judaism, not because of what they are today, but because of what they one day, according to Christian imagination, might become. However, a Christian theology of Judaism cannot be based on such a narrow understanding of eschatology. One of the first genuinely Christian experiences was that they gradually understood that the eschaton would not come as or when they thought. Slowly, inevitably, and painfully, they realized that they knew less than they previously thought. This piece of evidence should give us pause today as well. We need a third option; we need a solid rock upon which we can build Jewish-Christian relations in the future and for the future. Or, to use the library metaphor, we need to look for a third door in the biblical library.

This urge takes us to the third door, behind which we find the fifteenth chapter in Romans, in which we find a program which neither downgrades Judaism to a historical phenomenon, nor upgrades it in the future to something other than it is. I suggest in this article that Rom. 15 may serve as a more appropriate cornerstone than the two previously presented models. They portrayed a Judaism which was either passé or beyond the horizon. In addition, they tend to draw our attention to questions which, although interesting, primarily concern biblical scholars: what did Paul really mean when he used the expressions teolos nomou and mustêrion? In this third model, the biblical text serves less as a source text in an ongoing debate in the scholarly community which aims to reconstruct the history and theology of earliest Christianity, and all the more as a moral criterion for Jewish-Christian relations. Rom. 15 should serve as such a criterion in all Christian theologies. This agenda is in a way encapsulated in Rom. 15.8f.:

"For I tell you that Christ has become a servant of the circumcised on behalf of the truth of God [huper alêtheias Theou] in order that he might confirm the promises given to the ancestors [eis to bebaiôsai tas epangelias tôn paterôn], and in order that the Gentiles might glorify God for his mercy [ta de ethnê eleous doxasai ton Theon]."

These two verses in the fifteenth chapter of Paul's Epistle to the Romans give cause to three significant reflections.

First, Christian theologians should take pains to interpret their Scriptures in a way that convinces Jews that it is a theology which celebrates the truth of God and confirms the promises given to the matriarchs and patriarchs. What Rom. 15 reminds us of is that 
the challenge for Christians is to give vent to a theology which neither questions God's truthfulness (aletheia Theou) nor abrogates the promises (hai epangeliai), because a Christian theology which programmatically repudiates the Torah and its covenantal promises will present a capricious God; such a theology will certainly not live up to the standard. In his influential study The God of Israel and Christian Theology, R. Kendall Soulen distinguishes between three types of Christian supersessionism-structural, punitive, and economic - and he demonstrates that, being essentially divergent, they cannot be reconciled: structural supersessionism interprets the Hebrew Bible in such a way that the Jewish people and the Jewish tradition are eclipsed. Whereas punitive supersessionism argues that God abrogated the covenant with the Jewish people on account of the rejection of Jesus as Christ, economic supersessionism maintains that the role of the Jewish people always was meant to be transient (Soulen 1996, pp. 29-31). The only thing these three models have in common is that the render the existence of God's Israel a matter of indifference to the God of Israel, and that is why it is justifiable to argue that they present a capricious God.

A second reflection is that when Christians-i.e., Gentile Christians-hear this Christian proclamation, it should provoke them to give thanks for God's mercy (eleos). Some Christians might need to be reminded that they were simply not there from the beginning. Using a New Testament expression, they may have forgotten that they were invited to the vineyard only in the eleventh hour (cf. Matt. 20.1-16, esp. v. 6). I believe that such an eleventh-hour perspective could give cause for Christian respect for the Jewish tradition. Without this sense of humbleness, Christians easily fall prey to a deplorable-and perhaps even dangerous - theological triumphalism. In other words, the eleos which Paul emphasizes in Rom. 15.9 is an indication of Christians' recognition and appreciation of the relationship between the God of Israel and the Israel of God.

Thirdly, and finally, Rom. 15.8f. may serve as an opening door for a theology which acknowledges and celebrates diversity. It will remind Christians that the person and proclamation of Jesus of Nazareth will necessarily mean different things to Jews and Christians. On the one hand, a sound Christian proclamation would convince Jews that Christians do mean that God confirms the promises given to the Mothers and Fathers of old, and that God is faithful and truthful. On the other hand, Christians, remembering that the biblical drama has a magnificent pre-Christian part, will be grateful for God's mercy.

It is noteworthy that some Christians who emphasize gratefulness as a person's proper response when realizing what God has accomplished and nevertheless find it so difficult to remain grateful when confronted by vibrant Jewish life and spirituality. The reason for this inability to appreciate Judaism seems to be an inadequate reflection on the fact that the energeia of God, to use the Greek Orthodox terminology for how the essence (ousia) God is perceived by humans, must mean different things to Jews and Christians. A way to overcome this impasse is to consider that there is quite a distinct theological duality of "circumcised" and "Gentiles" in Pauline thinking in Rom. 15.8f.

In short, what is suggested here is that the fifteenth chapter in Romans best serves as a foundation for Jewish-Christian relations. In the first two models-related to the ninth and tenth chapters-Judaism is either historicized or apocalyptisized. The third approach concentrates on Judaism of today by encouraging Christians to articulate their belief in a way which reminds Jews and Christians alike that, according to both faiths, God is trustworthy - or, in the words of the Bible: rav chesed we-emet ("full of mercy and truth"; Ex. 34.6).

\section{Christianity as Fulfilment-What It Is and What It Is Not}

By way of conclusion, in what sense then is Christianity fulfilment? The answer is that, according to Christian belief, it is fulfilment in numerous ways: It is a fulfilment in terms of the inclusion of the gentiles into the covenant with the God of Israel (the center of Paul's mission, and also as presented in the introduction of this article, in the conversation between Jacob Taubes and Krister Stendahl), it is a fulfilment in terms of various manifestations that the Kingdom of God is at hand (arguably, it is the most important element in the teaching of 
Jesus, as presented and preserved in the Synoptic tradition), and it is a fulfilment in terms of the embodiment of the Word of God in Jesus of Nazareth (as articulated in the Johannine Prologue). In short, Christians see in the advent of Jesus of Nazareth numerous aspects of theological fulfilment.

There are, however, two major exceptions: Firstly, Christianity is never fulfilment in the sense that the eschaton is realized. The future is yet ahead. That is the very first lesson early Christianity was taught, and it took them some twenty years to learn that lesson: Christians are awaiting the future of God. With expressions taken from the realm of Pierre Teilhard de Chardin, God is not only the alpha, i.e., the God of Creation, but also the ômega, the God of the future (Teilhard de Chardin 1965, pp. 98-99).

Secondly, Christianity is never fulfilment at the expense of the promises given to the Mothers and Fathers of the covenant in the Scriptures. No Christian theological constructs can change that fact. This fundamental insight must be the corner stone of every Christian theological enterprise. Even if it took Christians some two thousand years to start learning that lesson, it is no less true than the first insight about the eschaton. As John Pawlikowski so beautifully phrased it a couple of years ago at a conference on Jewish-Christian relations, the pen that Paul used when writing Romans was waiting for two millennia, until cardinal Bea one day picked it up and wrote the first draft of Nostra Aetate. The Jews are, in the words of Paul and Nostra Aetate, agapêtoi and carissimi, "dearly beloved".

After two thousand years of supersessionism, it takes a lot of work to articulate a Christian theology which is fulfilment without supersessionism-but not as much work as the first generations of Christ believers had to devote to de-eschatologizing their message in order to be able to hand it over to future generations of Christians. They prevailed the challenge of their time-will we? They were set to articulate a theology which made sense in this world. Therefore, they were willing to strive, to seek, to find, and not to yield. Are we?

Funding: This research received no external funding.

Conflicts of Interest: The author declares no conflict of interest.

\section{Notes}

1 For an older version of this line of thought of Rom. 10,11, and 15 as a hermeneutical starting point for Jewish-Christian relations, see (Svartvik 2012, p. 315-30).

\section{References}

Baeck, Leo. 1958. Judaism and Christianity. Translated with an Introduction by Walter Kaufmann. New York: Leo Baeck Institute. Fredriksen, Paula. 2015. Why Should a 'Law-Free' Mission' Mean a 'Law-Free' Apostle? Journal of Biblical Literature 134: 637-50.

Fredriksen, Paula. 2017. Paul: The Pagans' Apostle. New Haven and London: Yale University Press.

Gager, John. 2002. Paul, the Apostle of Judaism. In Jesus, Judaism, and Christian Anti-Judaism: Reading the New Testament after the Holocaust. Edited by Paula Fredriksen and Adele Reinhartz. Louisville and London: Westminster John Knox, pp. 56-76.

Glancy, Jennifer A. 2002. Slavery in Early Christianity. Oxford: Oxford University Press.

Nirenberg, David. 2013a. Anti-Judaism as a Critical Theory. The Chronicle of Higher Education, January 28. Available online: www.chronicle.com/article/Anti-Judaism-as-a-Critical/136793/ (accessed on 5 February 2022).

Nirenberg, David. 2013b. Anti-Judaism: The Western Tradition. New York and London: Norton.

Sanders, Ed Parish. 1977. Paul and Palestinian Judaism: A Comparison of Patterns of Religion. Philadelphia: Fortress.

Sayers, Dorothy L. 2005. Are Women Human? Introduction by Mary McDermott Shideler. Grand Rapids and Cambridge: Eerdmans. First published 1947; Speech given in 1938.

Schürer, Emil. 1979. The History of the Jewish People in the Age of Jesus Christ (175 B.C.-A.D. 135). A New English Version Revised and Edited by Geza Vermes, Fergus Millar, Matthew Black. Edinburgh: T \& T Clark.

Schüssler Fiorenza, Elisabeth. 1993. But She Said: Feminist Practices of Biblical Interpretation. Boston: Beacon.

Shaer, Marie. 1986. Media Watch: Celebrating Women's Words. New Directions for Women 15: 6.

Sherwood, Yvonne. 2000. 'Colonizing the Old Testament' or 'Representing Christian Interests Abroad': Jewish-Christian Relations across Old Testament Territory. In Christian-Jewish Relations through the Centuries. Edited by Stanley E. Porter and Brook W. R. Pearson. Sheffield: Sheffield Academic Press, pp. 255-81.

Soulen, R. Kendall. 1996. The God of Israel and Christian Theology. Minneapolis: Fortress.

Stendahl, Krister. 1995. Final Account: Pauls Letter to the Romans. Foreword by Jaroslav Pelikan. Minneapolis: Fortress. 
Svartvik, Jesper. 2012. Geschwisterlichkeit: Realizing that We Are Siblings. In Kirche und Synagoge. Edited by Folker Siegert. Göttingen: Vandenhoeck \& Ruprecht, pp. 315-30.

Taubes, Jacob. 2004. The Political Theology of Paul. Translated by Dana Hollander. Stanford: Stanford University Press.

Teilhard de Chardin, Pierre. 1965. Hymn of the Universe. London: Collins.

Ucko, Hans. 1994. Common Roots, New Horizons: Learning about Christian Faith from Dialogue with Jews. Geneva: WCC Publications.

Zachman, Randall. 2019. Identity, Theology and the Jews: The Uses of Jewish Exile in the Creation of Christian Identity. In Antisemitism, Islamophobia, and Interreligious Hermeneutics: Ways of Seeing the Religious Other. Edited by Emma O'Donnell Polyakov. Leiden: Brill, pp. 51-67. 